\title{
Mutagen-Induced Diploid Human Lymphoblast Variants Containing Altered Hypoxanthine Guanine Phosphoribosyl Transferase
}

\author{
J. Epstein, ${ }^{1,2}$ A. Leyva, ${ }^{3}$ W.N. Kelley, ${ }^{3}$ and J.W. Littlefield ${ }^{1}$ \\ ${ }^{1}$ Department of Pediatrics, Johns Hopkins University School of Medicine, Baltimore, Mary- \\ land 21205 and ${ }^{3}$ Department of Internal Medicine, University of Michigan Medical Center, \\ Ann Arbor, Michigan 48104
}

Received 6 July 1976-_Final 19 October 1976

\begin{abstract}
The human lymphoblast line MGL8 was treated with HAT and subsequently "mutagenized" with EMS $(200 \mu \mathrm{g} / \mathrm{ml})$ to give $15 \%$ survival, and 6-thioguanine-resistant cells were selected by cloning in soft agarose containing the drug $(1 \mu \mathrm{g} / \mathrm{ml})$. Eighteen sublines of independently derived resistant clones were isolated and studied in detail. One subline had a low residual HGPRT activity of about $1 \%$ of the parental cells. The HGPRT of this subline had a higher $K_{m}$ for PRPP, was more sensitive to heat, and was degraded faster by trypsin than the enzyme in extracts of MGL8 cells. This resistant subline and three others contained CRM levels of 1$38 \%$, compared to the wild-type, so they probably represent true structural mutants of the HGPRT gene. All the variants maintained the karyotype of the parental line $\left(46, X Y, 6 p^{-}\right)$.
\end{abstract}

\section{INTRODUCTION}

Diploid cell lines with stable karyotypes are advantageous for genetic studies, since variation in aneuploid cells may reflect changes other than point mutations, such as rearrangement or loss of chromosomal material or perhaps epigenetic phenomena, which are poorly understood at present (1-5). The growth characteristics of human lymphoblast lines in culture (6) make these cells a favorable model for mutagenesis studies aimed at investigating the molecular genetics of enzymes. Sato et al. (7), Lever et al. (8), and Nyoromi et al. (9) have reported the selection of HGPRT (hypoxanthine guanine phosphoribosyltransferase)-deficient variants from human lymphoblast lines that have normal HGPRT activity. The purpose of this paper is to describe the diverse biochemical and im-

${ }^{2}$ The address for reprint requests is J. Epstein, Laboratory of Experimental Oncology, Indiana University Medical Center, Indianapolis, Indiana 46202.

1977 Plenum Publishing Corp., 227 West 17th Street, New York, N.Y. 10011. To promote freer access to published material in the spirit of the 1976 Copyright Law, Plenum sells reprint articles from all its journals. This availability underlines the fact that no part of this publication may be reproduced, stored in a retrieval system, or transmitted, in any form or by any means, electronic, mechanical, photocopying, microfilming, recording, or otherwise, without written permission of the publisher. Shipment is prompt; rate per article is $\$ 7.50$. 
munochemical characteristics of 18 6TG (6-thioguanine)-resistant clonal lines derived from a human lymphoblast line after "mutagenesis" with EMS (ethylmethane sulfonate). All the cells in all these variant sublines maintained the parental karyotype of $46, X Y, 6 p^{-}$. Four variants contained significant amounts of CRM and most likely represent true mutants in the structural gene for HGPRT.

\section{METHODS}

\section{Cell Cultures}

The human lymphoblast cell line MGL8 was established by Dr. H. R. Zielke from a blood sample from a 28-yr-old healthy male donor, according to the method of Beratis and Hirschhorn (10). The cells were maintained in static suspension culture in Roswell Park Memorial Institute 1640 medium (GIBCO) supplemented with $15 \%(\mathrm{v} / \mathrm{v})$ fetal calf serum (MBA), and were incubated at $37^{\circ} \mathrm{C}$ in a $5 \%(\mathrm{v} / \mathrm{v}) \mathrm{CO}_{2}$ atmosphere. The cultures were passed twice weekly at $2 \times 10^{5} \mathrm{cells} / \mathrm{ml}$, and showed a doubling time of $26-30 \mathrm{hr}$ with a final yield of $1.5 \times 10^{6} \mathrm{cells} / \mathrm{ml}$. Cell numbers were determined with a Coulter Electronics model $Z_{B} I$ counter. All the cultures were periodically tested and found free of mycoplasma contamination by the culture method (11) and by the uridine/uracil incorporation ratio (12). The MGL8 cells are diploid except for a deletion in the short arm of chromosome No. 6, which was acquired after several months in culture and is present in all cells, providing a useful marker.

\section{Cloning in Soft Agarose}

Cells were mixed in $2 \mathrm{ml}$ medium containing $0.22 \%$ agarose (Marine Colloids) and layered over $2.5 \mathrm{ml}$ of a $0.24 \%$ agarose medium separating layer in a $60-\mathrm{mm}$ petri dish (7). Monolayers of diploid fibroblasts from a patient with Lesch-Nyhan syndrome were used as the "feeder" layer.

\section{Treatment with Mutagen}

To determine the response of the wild-type MGL8 cells to mutagen treatment, exponentially growing cells were exposed to varying concentrations of EMS in culture medium for $20 \mathrm{hr}$. The cells were then counted, washed in fresh warm RPMI 1640 medium, and resuspended in fresh medium to the initial volume. The growth of the culture was followed by daily counts. This was important for maximal recovery of variants. Cells treated with $200 \mu \mathrm{g} / \mathrm{ml}$ of EMS showed $15-20 \%$ survival immediately after treatment, but they needed 9-12 days to completely recover, at which time the cloning efficiency finally reached a level equal 
to that of untreated control cells. The cloning efficiency of MGL8 varied in different experiments between $15 \%$ and $29 \%$ but was consistant in all the replicate plates (at least four) used in each experiment.

\section{HGPRT Activity}

Cell Extracts. Logarithmically growing cells were washed two times in cold PBS by centrifugation, and then resuspended in $0.01 \mathrm{M}$ phosphate $\left(\mathrm{K}^{+}\right)$buffer, $\mathrm{pH} 6.8$, containing $0.25 \mathrm{M}$ sucrose. The cell suspensions containing $10^{7} \mathrm{MGL} 8$ cells $/ \mathrm{ml}$ or $10^{8}$ mutant cells $/ \mathrm{ml}$ were lysed by freezethawing three times in a dry-ice-ethanol bath. Following a 30-min centrifugation at $24,000 \mathrm{~g}$, the supernatants were diluted in $10^{-2} \mathrm{M}$ phosphate buffer, $\mathrm{pH} 6.8$, containing sucrose $(0.25 \mathrm{M})$ and bovine serum albumin (BSA) $(1 \mathrm{mg} / \mathrm{ml})$. Dilution ratios were 1:10 for the normal ex tracts and 1:2 for those of the resistant cells. All extracts were stored at $-70^{\circ} \mathrm{C}$, and thawed immediately before the assay for enzyme activity. Protein concentrations in the extracts were determined by the method of Lowry et al. (13).

Enzyme Assay. HGPRT activity was determined by a radiochemical assay. The final reaction mixture of $50 \mu \mathrm{l}$ contained $50 \mathrm{mM}$ potassium phosphate buffer, pH $7.4,5 \mathrm{mM} \mathrm{MgCl}_{2}, 1 \mathrm{mM}$ PRPP, $20 \mu \mathrm{m}{ }^{14} \mathrm{C}$ hypoxanthine $(12-50 \mu \mathrm{Ci} / \mathrm{m}$ mole), and $25 \mu \mathrm{l}$ of the diluted cell extracts. The reaction mixtures were incubated at $37^{\circ} \mathrm{C}$. Incubation time was 15 min for the normal lysate and from $45 \mathrm{~min}$ to $2 \mathrm{hr}$ for the lysates of the resistant cells. The reaction was stopped by the addition of $5 \mu \mathrm{l}$ of $0.27 \mathrm{M}$ EDTA and rapid chilling to $0-2^{\circ} \mathrm{C}$. A $25-\mu$ laliquot of the reaction mixture was spotted on a DEAE disk (Whatman DE81). The disks were air-dried, washed twice in $1 \mathrm{mM}$ ammonium formate, once in water, and finally in $70 \%$ ethanol. Then the disks were dried under a drying lamp, and radioactivity was counted in a liquid scintillation counter. Enzyme activity was also assayed at $\mathrm{pH} 10.0(100 \mathrm{mM}$ glycine- $\mathrm{NaOH})$ (Nash and Johnson, unpublished) or in the presence of $33 \mathrm{mM} \mathrm{MgTTP}$ to inhibit nucleotidase activity. In this case products were separated by high-voltage electrophoresis. Enzyme activities were found to be essentially identical under these different assay conditions.

\section{Determination of Immunologically Cross-Reacting Material (CRM)}

Cell Extracts. Cells $\left(4.6-6.5 \times 10^{8}\right)$ stored at $-70^{\circ} \mathrm{C}$ were extracted at $4^{\circ} \mathrm{C}$ with $0.6-0.7 \mathrm{ml} 0.05 \mathrm{M}$ potassium phosphate, $\mathrm{pH} 7.4$, by freezethawing twice in a dry-ice-acetone bath. Lysates were centrifuged for 20 min at $10,000 \mathrm{~g}$, and the supernatants were dialyzed against 400 volumes of the same buffer at $4^{\circ} \mathrm{C}$ overnight with one change of buffer. Dialyzed cell extracts were stored at $-70^{\circ} \mathrm{C}$ until the time of assay. 
The immunoprecipitation-inhibition assay was performed in $50 \mu \mathrm{l}$ reaction mixtures containing $2.75 \mu \mathrm{g}$ of wild-type lymphoblast extract protein plus varying amounts of wild-type or HGPRT-deficient cell extract, $25 \mu$ l of rabbit anti-HGPRT serum (15) diluted 1/512 (the antiserum was diluted with nonimmune serum diluted $1 / 128), 0.15 \mathrm{M} \mathrm{NaCl}, 0.05 \mathrm{M}$ potassium phosphate, $\mathrm{pH} 7.4$, and $1.5 \mathrm{mM} \mathrm{Mg}$ PRPP. After incubation at $37^{\circ} \mathrm{C}$ for $30 \mathrm{~min}$ and then at $4^{\circ} \mathrm{C}$ for $2-4 \mathrm{hr}, 25 \mu \mathrm{l}$ of goat antirabbit IgG serum diluted $1 / 4$ was added, and the reaction mixtures were incubated at $37^{\circ} \mathrm{C}$ for $30 \mathrm{~min}$ and $4^{\circ} \mathrm{C}$ for $12-18 \mathrm{hr}$. The immunochemical precipitate was collected by centrifugation at $1,000 \mathrm{~g}$ for $20 \mathrm{~min}$ at $4^{\circ} \mathrm{C}$, and the supernatant was assayed for HGPRT activity. Enzyme activity contributed by the antiserum was subtracted, and the percent of HGPRT activity specifically precipitated by anti-HGPRT serum was determined. At least $95 \%$ of the HGPRT activity was precipitated in the presence of excess anti-HGPRT serum.

Immunochemical titration was performed in a similar manner except that the amount of cell extract was kept constant and the dilution of rabbit anti-HGPRT serum was varied from $1 / 64$ to $1 / 512$. Nonimmune serum was included to keep the total rabbit serum concentration constant at a 1/64 dilution, and a $1 / 2$ dilution of goat antirabbit IgG serum was used.

\section{RESULTS}

\section{Sensitivity to 6TG}

To determine the sensitivity of the cell line MGL8 to the selective procedure, cells were cloned at various densities in soft agarose (7) containing $6 \mathrm{TG}$ at several concentrations. Sensitivity was indicated by the proportion of visible colonies formed compared to controls. Figure 1 shows the results of these experiments. About $4 \%$ of the cells survived selection with $0.3 \mu \mathrm{g} / \mathrm{ml}$ 6TG. Only rare colonies were found when $1 \mu / \mathrm{ml}$ was used, and the frequency was not reduced by using $3 \mu \mathrm{g} / \mathrm{ml}$ of the drug. These colonies at $1 \mu \mathrm{g} / \mathrm{ml}$ were formed by preexisting 6TG-resistant cells at a frequency of $3 \times 10^{-6}$ colonies/cell plated; pretreatment with HAT $(16,17)$ decreased the frequency to a minimum of $3 \times 10^{-7}$ colonies/cell plated. Thereafter we used for selection $6 \mathrm{TG}$ at a concentration of $1 \mu \mathrm{g} / \mathrm{ml}$.

Albertini and DeMars (18), Orkin and Littlefield (19), and Sato et al. (7) have reported that the recovery of rare resistant cells is decreased when the cell density in the selection plates is increased. To determine the effect of high density of MGL8 cells on the recovery of variants, we first obtained a 6TG-resistant variant by selection in mass culture. After 


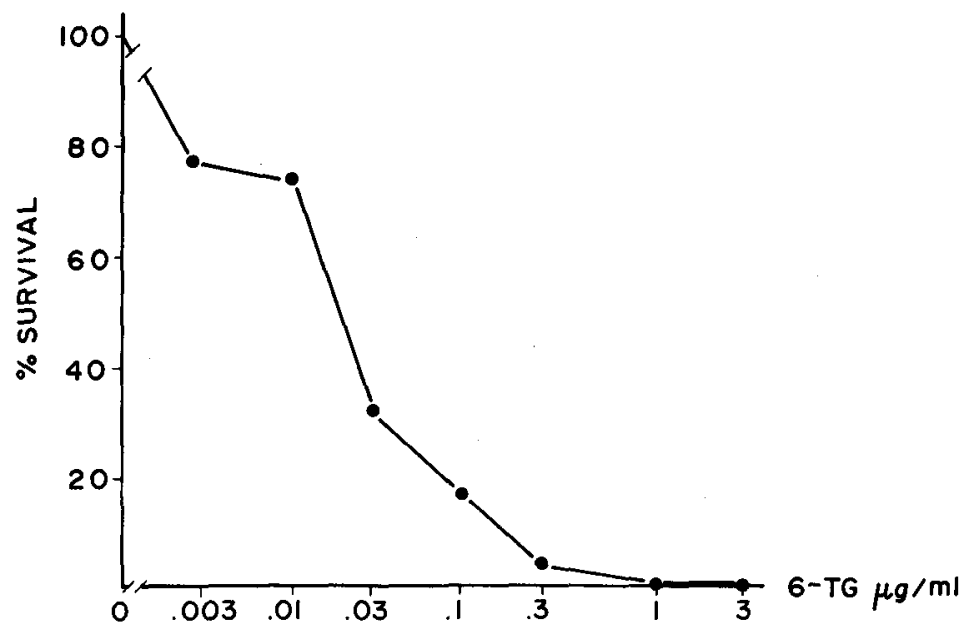

Fig. 1. Sensitivity of MGL8 to 6-thioguanine. $3 \times 10^{2}-1 \times 10^{6}$ cells were plated in soft agarose containing $6 \mathrm{TG}$ at $0,0.003,0.01,0.03,0.1,0.3,1$, and $3 \mu \mathrm{g} / \mathrm{ml}$. The cloning efficiency in the absence of $6 \mathrm{TG}$ was $18 \%$. The percent of surviving colonies corrected for cloning efficiency was plotted against drug concentration. For each point 6-10 dishes were scored.

recovery from EMS treatment, $10 \mathrm{ml}$ cultures containing approximately $5 \times 10^{6}$ cells were refed twice weekly with RPMI 1640 medium containing $6 \mathrm{TG}$ at $1 \mu \mathrm{g} / \mathrm{ml}$. After about 3 weeks, cell populations emerged that were resistant to high levels of $6 \mathrm{TG}$. We used these cells for a reconstruction experiment as follows: 300 of the $6 \mathrm{TG}^{\mathrm{R}}$ cells were cloned in $2 \mathrm{ml}$ of soft agarose containing $6 \mathrm{TG}$ in the presence of $0,5 \times 10^{4}, 5 \times 10^{5}$, and $1 \times 10^{6}$ sensitive MGL8 cells, and the cloning efficiencies were compared. The results are summarized in Table 1 . Based on these results we chose to use a density of $5 \times 10^{5}$ cells per plate for an efficient selection of resistant cells.

\begin{tabular}{ccc}
\hline & Table 1. Summary of Results & \\
\hline $\begin{array}{c}\text { Variant } \\
\text { cells/plate }\end{array}$ & $\begin{array}{c}\text { MGL8 } \\
\text { cells/plate }\end{array}$ & $\begin{array}{c}\text { Cloning } \\
\text { efficiency (s.d.) }\end{array}$ \\
\hline $3 \times 10^{2}$ & 0 & $8 \%(1)$ \\
$3 \times 10^{2}$ & $5 \times 10^{4}$ & $12 \%(3)$ \\
$3 \times 10^{2}$ & $5 \times 10^{5}$ & $6 \%(1.5)$ \\
$3 \times 10^{2}$ & $1 \times 10^{6}$ & $3 \%(1.3)$ \\
\hline${ }^{a}$ HGPRT-deficient variant cells, derived from MGL8 by mass culture selection after \\
"mutagenesis," were plated in soft agarose containing 6-thioguanine $(1 \mu \mathrm{g} / \mathrm{ml})$ with MGL8 \\
cells. For each point 6 replicate plates were scored.
\end{tabular}




\section{Isolation of Variants}

Exponentially growing MGL8 cells were treated with HAT for 6-8 days. The medium was changed to medium containing adenine $\left(1 \times 10^{-5}\right.$ $\mathrm{M})$, thymidine $\left(2 \times 10^{-4} \mathrm{M}\right)$, and EMS $(200 \mu \mathrm{g} / \mathrm{ml})$. After $20 \mathrm{hr}$ the culture was centrifuged for $10 \mathrm{~min}$ at $300 \mathrm{~g}$, the medium was discarded, and the cell pellet was resuspended in fresh medium to the original volume and divided into several $10-\mathrm{ml}$ cultures. Survival was tested by cloning in soft agarose, and the recovery pattern was followed by daily cell counts. During the recovery period the cells were refed every 3 days by replacing onehalf of the medium with fresh medium. When fully recovered, the cells were cloned in soft agarose containing 6TG $(1 \mu \mathrm{g} / \mathrm{ml})$ at a density of $5 \times$ $10^{5}$ cells per $60-\mathrm{mm}$ dish. Three to four weeks later all the dishes had colonies of various sizes. The frequency of $6 \mathrm{TG}$-resistant colonies was increased approximately 16-fold by EMS. From each group of selection dishes into which cells had been inoculated from one culture flask, a few of the bigger colonies were isolated and propagated into lines. Of these only one line, chosen arbitrarily or because of rapid growth, was characterized further, in order to assure the use of independently derived variant lines. The resulting cultures of 6TG-resistant cells were identified as the MGL8A lines (e.g., A18), and were tested to determine the degree and nature of their resistance by observing their growth in the presence of increasing amounts of 6TG and in HAT medium, as compared to growth in regular medium alone. Also the activity of HGPRT was determined for all resistant cells, and the presence of HGPRT protein tested by immunochemical assay.

In all, we measured the growth properties, HGPRT enzyme activity, and presence of CRM (immunologically cross-reacting material) in 18 sublines originating from 18 independently "mutagenized" cultures.

\section{Enzyme Activity}

The 6TG-resistant lines were subcultures at $2 \times 10^{5} \mathrm{cells} / \mathrm{ml}$ into medium containing $6 \mathrm{TG}$ at concentration of up to $10 \mu \mathrm{g} / \mathrm{ml}$. They grew at rates comparable to that of controls subcultured in regular medium. All the lines with the exception of A30 were killed by exposure to HAT medium for 3-5 days. Line A30 did not grow in HAT, but was not killed under these conditions even after 30 days of treatment, and could be rescued by removing the HAT and feeding with regular medium. When assayed for HGPRT activity, extracts of the normal MGL8 cells showed a specific activity of $400 \mathrm{nmoles} / \mathrm{mg}$ protein $/ \mathrm{hr}$ (s.d. 7\%). Of the resistant lines only the A30 extract had a significantly detectable level of HGPRT activity, $4 \mathrm{nmoles} / \mathrm{mg}$ protein $/ \mathrm{hr}$. Line A29 had a doubtfully significant enzyme activity level of 0.5-0.7 nmoles $/ \mathrm{mg}$ protein $/ \mathrm{hr}$, and the activity level of the other extracts was lower than $0.1 \mathrm{nmole} / \mathrm{mg}$ protein $/ \mathrm{hr}$. The 
HGPRT activity of the cell extracts remained unchanged under the different assay conditions as specified in the methods, with one exception. The activity of $\mathrm{A} 30$ alone was increased two-fold when assayed at $\mathrm{pH} 10$. This suggests a structural change in the enzyme protein.

We compared the kinetic behavior of the A30 enzyme to that of MGL8. Figure 2a shows that the A30 HGPRT has a $K_{m}$ value for
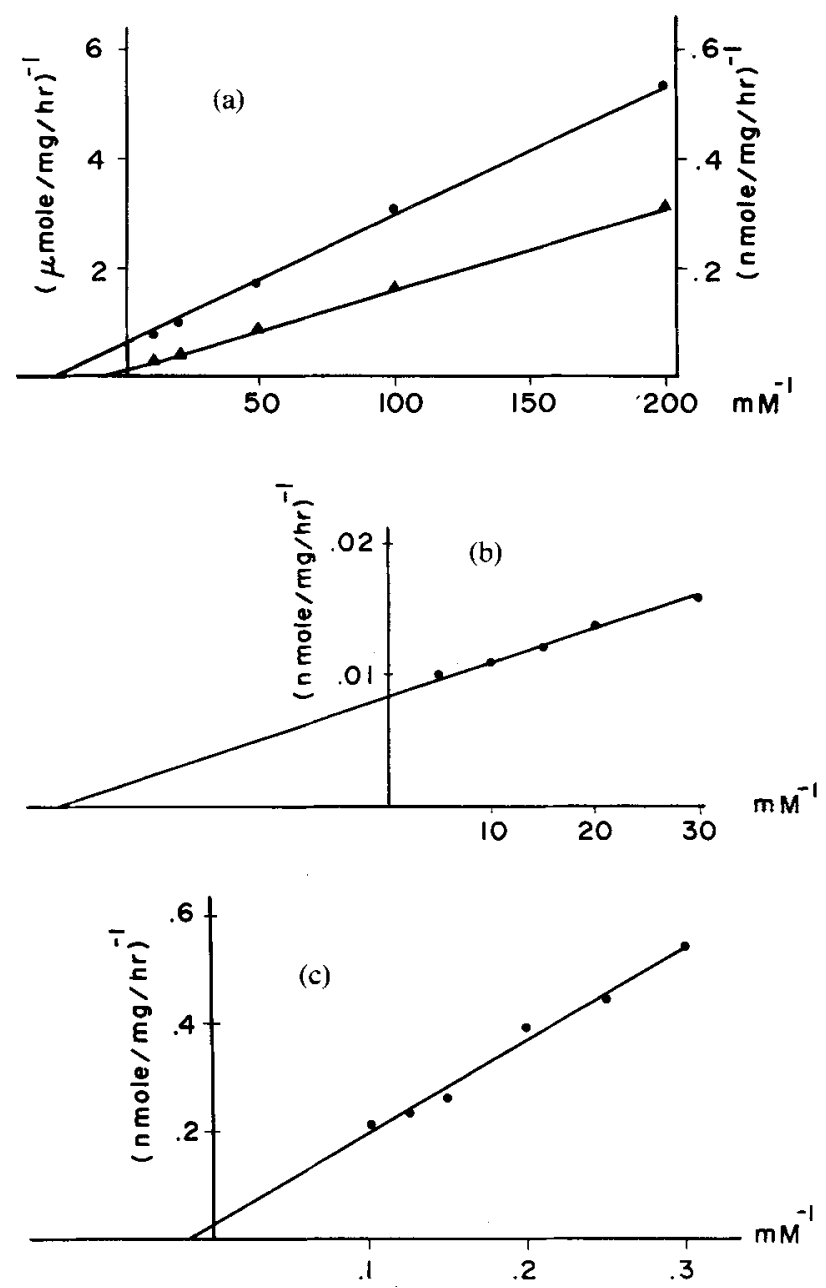

Fig. 2. Kinetic behavior of HGPRT in MGL8 and A30 extracts. Cells were lysed and extracts prepared and assayed for HGPRT activity as described in Materials and Methods section. (a) Double reciprocal plot of enzyme activity against hypoxanthine concentration. $\bullet-$ - $\operatorname{MGL8}\left(K_{m}=4.5 \times 10^{-5} \mathrm{M}, V_{\text {max }}=2 \times 10^{-6} \mathrm{~mole} / \mathrm{mg} / \mathrm{hr}\right), \Delta-\Delta \mathrm{A} 30\left(K_{m}=1.2 \times 10^{-4} \mathrm{M}\right.$, $V_{\max }=7.1 \times 10^{-8} \mathrm{~mole} / \mathrm{mg} / \mathrm{hr}$ ). (b) and (c) Double reciprocal plots of HGPRT activity against concentration of PRPP. The concentration of $\mathrm{Mg}^{++}$was kept at 5 times that of PRPP. (b) MGL8 $\left(K_{m}=3.1 \times 10^{-5} \mathrm{M}, V_{\max } \times 1.2 \times 10^{-7} \mathrm{~mole} / \mathrm{mg} / \mathrm{hr}\right)$; (c) $\mathrm{A} 30\left(K_{m}=6 \times 10^{-2} \mathrm{M}\right.$, $V_{\max }=4 \times 10^{-8} \mathrm{~mole} / \mathrm{mg} / \mathrm{hr}$ ). 
hypoxanthine of $1.2 \times 10^{-4}$, compared to $4.5 \times 10^{-5} \mathrm{M}$ for MGL8. A com. parison of the data presented in Figures $2 b$ and $2 c$ shows that the PRPP (phosphoribosylpyrophosphate) $K_{m}$ value of A30 is $6 \times 10^{-2} \mathrm{M}$, three orders of magnitude higher than the corresponding $K_{m}$ value for MGL8, $3 \times 10^{-5} \mathrm{M}$. We further compared the heat stability and the inactivation by trypsin of HGPRT in the A30 extract to HGPRT in the MGL8 extract. To determine heat inactivation, dialyzed extracts of MGL8 and A30 cells, diluted to a protein concentration of $5 \mathrm{mg} / \mathrm{ml}$, were heated at $80^{\circ} \mathrm{C}$ for $0-$ $48 \mathrm{~min}$, chilled rapidly, and centrifuged at $10,000 \mathrm{~g}$ for $20 \mathrm{~min}$. Then the supernatants were assayed for HGPRT activity. Figure 3 shows that the extract of A30 loses its HGPRT activity much faster than MGL8. Heating at $80^{\circ} \mathrm{C}$ for 4 min resulted in a loss of $98 \%$ of the initial activity, compared to a loss of less than $10 \%$ of the MGL8 activity. To determine the inactivation of HGPRT by trypsin, $100 \mu$ l aliquots of dialyzed extract diluted to a protein concentration of $6 \mathrm{mg} / \mathrm{ml}$ were incubated with $10 \mu$ l of trypsin (Sigma, $3 \mathrm{mg} / \mathrm{ml}$ ) at $25^{\circ} \mathrm{C}$ for $0-20 \mathrm{~min}$. The proteolytic reaction was stopped by the addition of $10 \mu \mathrm{l}$ of soybean trypsin inhibitor (Sigma, 6 $\mathrm{mg} / \mathrm{ml}$ ), and the reaction mixture was assayed for HGPRT activity. As Fig. 4 shows, the A30 enzyme was inactivated by trypsin much faster than

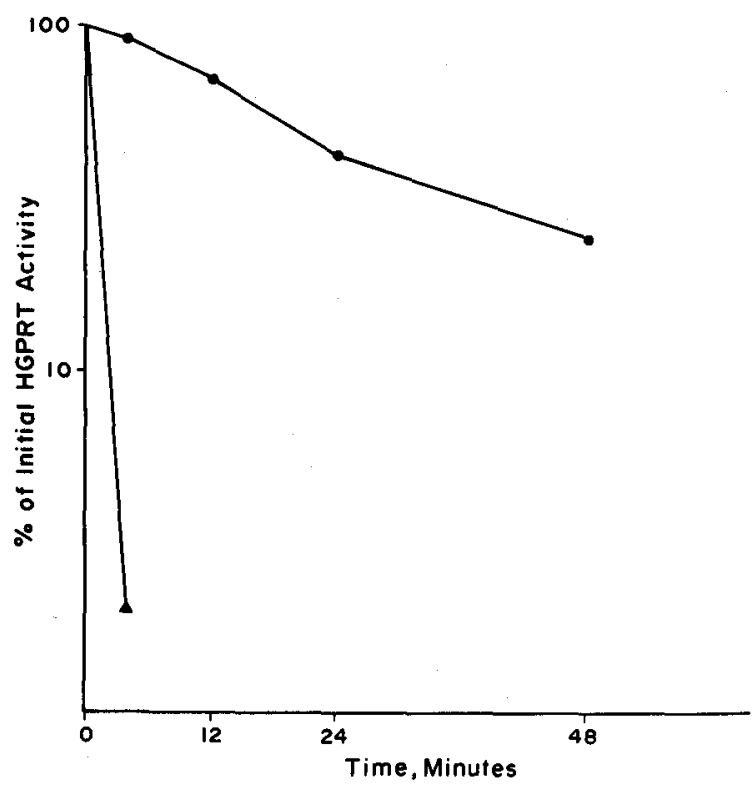

Fig. 3. Heat inactivation of HGPRT activity. Extracts at $5 \mathrm{mg}$ protein/ml were heated at $80^{\circ} \mathrm{C}$ for $0-48 \mathrm{~min}$, chilled rapidly, and centrifuged at $10,000 \mathrm{~g}$ for $20 \mathrm{~min}$. The residual activities in the supernatant fluids, expressed as percent of the initial activity, were plotted against time of incubation. - MGL8 (initial activity 23,705 cpm); _ A30 (initial activity $650 \mathrm{cpm})$. 


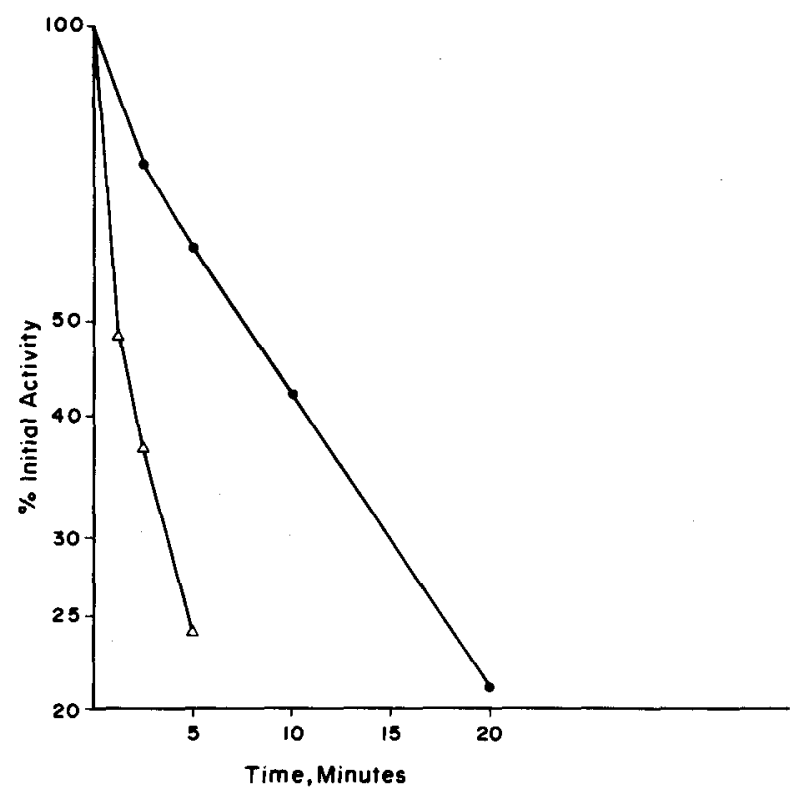

Fig. 4. Trypsin inactivation of HGPRT activity. Extracts at $6 \mathrm{mg}$ protein/ml were incubated at $25^{\circ} \mathrm{C}$ with $10 \mu \mathrm{l}$ of trypsin $(3 \mathrm{mg} / \mathrm{ml})$. The proteolytic reaction was stopped with $10 \mu \mathrm{l}$ of trypsin inhibitor $(6 \mathrm{mg} / \mathrm{ml})$. Residual HGPRT activity was plotted against time of incubation. $\bullet$ MGL8 (initial activity $17,518 \mathrm{cpm}$ ), $\triangle \longrightarrow \triangle \mathrm{A} 30$ (initial activity $493 \mathrm{cpm}$ ).

the wild-type HGPRT. After 5 min of incubation, $76 \%$ of the A30 activity was lost, compared to $41 \%$ of the MGL8 activity. In summary, the HGPRT of the variant line differed from the enzyme of the wild-type parental line MGL8 in regard to the $\mathrm{pH} 10 / 7.4$ activity ratio, sensitivity to heat, rate of inactivation by trypsin and $K_{m}$ value for PRPP.

\section{Immunochemical Determinations}

Variant cell extracts with markedly reduced or undetectable levels of HGPRT activity were examined for the presence of material cross-reacting immunologically (CRM) to normal HGPRT by the method of immunoprecipitation inhibition. In a standard immunoprecipitation reaction, with constant amounts of wild-type MGL8 extract (2.75 $\mu \mathrm{g}$ protein) and antiserum ( $25 \mu \mathrm{l}$ of $1 / 512$ dilution), 33\% of the initial HGPRT activity remained unprecipitated. The addition of increasing amounts of wild-type extract resulted in an increase in the percent of unprecipitated HGPRT activity approaching $100 \%$, which was interpreted as the inhibition of the precipitation capacity of HGPRT antibody due to antigen excess. Figure 5 illustrates the immunoprecipitation-inhibition curves for MGL8 and 6 representative mutant extracts, and demonstrates the various different 


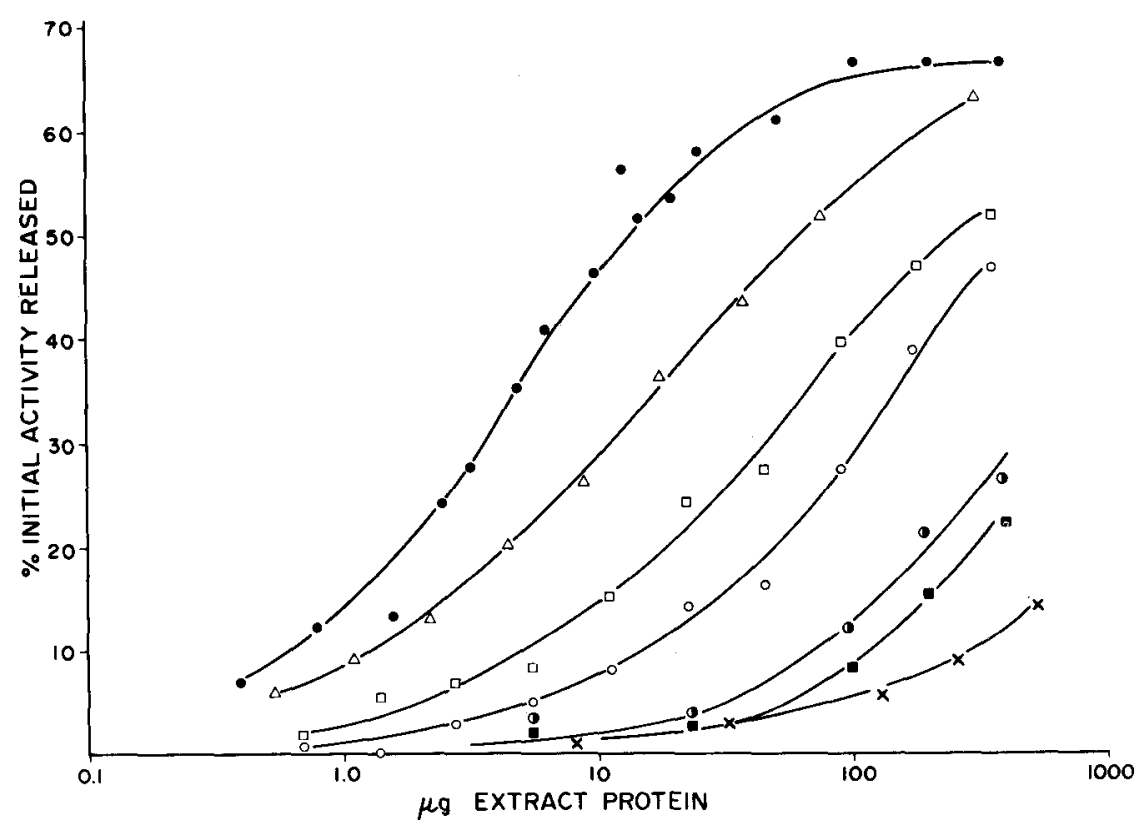

Fig. 5. Demonstration of CRM in mutant cell extracts by immunoprecipitation-inhibition. Immunochemical reaction mixtures contained $2.75 \mu \mathrm{g}$ of wild-type extract protein, $0.40-500$ $\mu \mathrm{g}$ of additional wild-type or mutant extract protein, and $25 \mu \mathrm{l}$ of antiserum or nonimmune serum. In the absence of additional extract, supernatant HGPRT activity with nonimmune serum (initial activity) was $859 \mathrm{cpm}$ and was reduced to $33 \%$ of this value with antiserum. For reactions with additional extract the percent of HGPRT activity unprecipitated by antiserum was determined, and the percent value above $33 \%$ was plotted versus the amount of

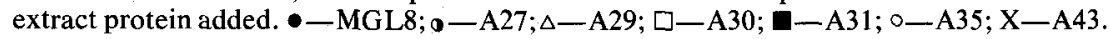

levels of CRM found in this series of HGPRT-deficient variant cell lines. Quantitation of CRM in variant extracts was done by graphic determination of the amounts of wild-type and variant extract protein required to produce a similar increase in the percent of unprecipitated HGPRT activity, followed by calculation of the percent CRM relative to wild-type according to the formula,

$$
\frac{\mu \mathrm{g} \text { wild-type protein }}{\mu \mathrm{g} \text { variant protein }} \times 100
$$

All experimental points in which there was an increase of at least $7 \%$ in the residual activity were used to calculate CRM levels. Accurate quantitation of CRM by this method would require that the shape of the variant immunoprecipitation-inhibition curve be closely similar to that of wildtype HGPRT. At least two variant extracts, A29 and A30, yielded curves with slightly altered shapes, which contributed some degree of error (expressed in s.d., Table 2). As Fig. 5 demonstrates, when enough of the 


\begin{tabular}{lccccc}
\hline \multicolumn{6}{c}{ Table 2. Properties of 6TG-Resistant Mutants } \\
\hline Cell & $\begin{array}{c}\text { HGPRT } \\
\text { nmole/mg hr }\end{array}$ & $\begin{array}{c}\text { Growth in } \\
\text { 6TG }(10 \mu \mathrm{g} / \mathrm{ml})\end{array}$ & $\begin{array}{c}\text { Killed by } \\
\text { HAT }\end{array}$ & $\begin{array}{c}\text { CRM } \\
\text { \% of MGL8 }\end{array}$ & Karyotype \\
\hline MGL8 & 400 & - & - & & $46, X Y, 6 p^{-}$ \\
A27 & $<0.1$ & + & + & $1 \pm 0.2$ & $46, X Y, 6 p^{-}$ \\
A29 & 0.6 & + & + & $38 \pm 15$ & $46, X Y, 6 p^{-}$ \\
A30 & $4^{a}$ & + & - & $10 \pm 5$ & $46, X Y, 6 p^{-}$ \\
A35 & $<0.1$ & + & + & $4 \pm 1$ & $46, X Y, 6 p^{-}$ \\
Other 14 & $<0.1$ & + & + & $<0.6$ & $46, X Y, 6 p^{-}$ \\
\hline
\end{tabular}

${ }^{a}$ Determined at $1 \mathrm{mM}$ PRPP; see text and caption to Fig. 2 for $V_{\max }$ values.

MGL8 extract was added, the competition was complete and full recovery of the initial HGPRT occurred. This is expressed in Fig. 5 as a maximal recovery level of $67 \%$ of the initial activity, since $33 \%$ of the initial activity remained unprecipitated.

Four of the variants had significantly detectable levels of CRM. A29 had about $38 \%$ and A27 had the lowest detectable level, $1 \%$. The rest of the mutant lines showed a very low level of competition, detectable only when very high volumes of extract were added; calculated CRM values were $0.2-0.6 \%$ of the normal, which in our assay system is not significant.

The antigenicity of the A30 CRM, which had a low but detectable

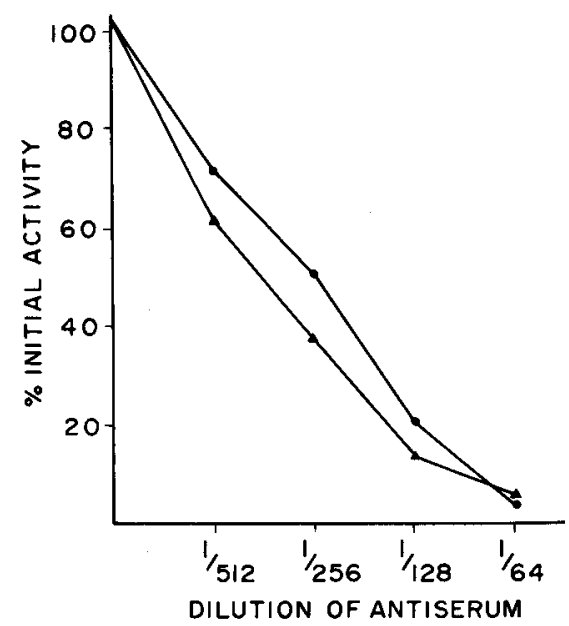

Fig. 6. Immunochemical titration of wild-type and mutant cell HGPRT. Immunochemical reaction mixtures contained either $8.25 \mu \mathrm{g}$ of MGL8 (wild-type) extract protein or $82.5 \mu \mathrm{g}$ of A30 (HGPRT-deficient variant) extract protein. The initial HGPRT activities (with nonimmune serum only) for MGL8 and A30 were 2757 and $595 \mathrm{cpm}$, respectively. Enzyme assays were performed as described in Materials and Methods section except that A30 HGPRT was assayed in the presence of $10 \mathrm{mM} \mathrm{MgPRPP}$ for $2 \mathrm{hr}$. HGPRT activity unprecipitated by antiserum was expressed as percent of initial activity and plotted versus concentration of antiserum. •-MGL8; $\triangle$-A30. 
level of activity, was compared to that of the MGL8 enzyme by a direct method of immunochemical titration. Figure 6 shows that when increasing amounts of antiserum were added to the cell extracts, the A30 extract yielded a precipitation curve very similar to that of the MGL8 enzyme. This similarity between the precipitation curves suggests that the HGPRT molecules present in the A30 cells have the same antigenicity as MGL8 HGPRT, and are therefore recognized equally by the anti-HGPRT antibodies.

\section{DISCUSSION}

We have treated a diploid human lymphoblast line with EMS and selected a series of independent 6TG-resistant clonal sublines. The ability to clear the cultures of preexisting HGPRT-deficient cells facilitates the selection from separate cultures of variant cells that are the results of independent events.

Phenotype alteration in cells may result from changes other than true mutations. These may involve changes in chromosome number, reorganization of chromosomes, poorly understood epigenetic processes, and other events not related to the primary structure of genes (1-4). All our 6TG-resistant cells, including lines with or without CRM, maintained the Q-banded karyotype of the parent cell line without detectable change. Therefore, a presently detectable cytogenetic change did not cause the variation.

The highest residual HGPRT activity measured in the variants was at the level of $1 \%$ of the normal. This might suggest that the concentration of $6 \mathrm{TG}$ employed for selection was too high to allow survival of cells with more residual enzyme activity. However, the A30 cells that showed this level of activity could not be killed by HAT, which suggests that a relatively low level of enzyme activity is required for sufficient phosphoribosylation of hypoxanthine. The maximal velocity of HGPRT activity in MGL8 cells, calculated on a cellular basis, is about $10^{5}$ times higher than the maximal rate at which hypoxanthine enters the cells (23). Thus transport appears to be rate-limiting in the incorporation of the purine base into nucleic acids $(23,24)$. 6TG must be phosphoribosylated by HGPRT in order to exert its toxic effect; and based on what was shown for hypoxanthine, we feel that in cells with measurable enzyme activity, in which the enzyme's affinity for 6TG is not drastically reduced, the rate at which the drug enters the cell determines the effectiveness of the selection system. The data presented in Fig. 1 indicate that lowering the concentration of $6 \mathrm{TG}$ in the selection plates decreases the effectiveness of the system for the selection of cells resistant to the drug, probably because of an uptake barrier. Therefore, when enough $6 \mathrm{TG}$ is used to kill all 
sensitive cells, only mutants with very little or no residual HGPRT activity will survive the selection.

Four of the resistant lines had detectable amounts of CRM. Among these A29 showed the highest level of $38 \%$, and A30 retained some catalytic activity in addition to 10\% CRM. The low levels of CRM in the CRM-positive mutants could be explained by high sensitivity to heat or trypsin, as is evident in Figs. 3 and 4 for the A30 enzyme. Capecchi et al. reported that abnormal HGPRT proteins are selectively degraded in CRM-positive variant mouse cells, and that the rates of degradation determine the concentrations of these proteins in such cells (25). The residual HGPRT activity in extracts of A30 was also different from the normal in its kinetic behavior and in the $\mathrm{pH} \mathrm{10/7.4} \mathrm{activity} \mathrm{ratio.} \mathrm{All} \mathrm{these} \mathrm{results}$ suggest that $\mathrm{A} 30$ has a true mutation in the structural gene for HGPRT. It is likely that the other CRM-positive lines also contain structural gene mutations, although possibilities such as posttranslation modification cannot be excluded at present.

Altered levels of immunologically reactive material might reflect altered antigenicity of the variant protein, rather than just the amount of enzyme protein present. The experiment summarized in Fig. 6 suggests that for A30 cells this was not the case. When equal amounts of antigenically reactive material of both the normal parent and the variant cell line were used, similar precipitation curves were observed. This strongly suggests that the antigenicity of the variant protein is similar to that of the normal cells, and that the CRM level is a quantitative measure. Also suggested by the similarity of the two curves is that the residual enzyme activity is evenly distributed among the one type of precipitable molecules present in the variant cells.

We have described a series of HGPRT-deficient variants derived independently from a diploid human lymphoblast line. Four of these sublines have various levels of CRM, and one of these retained a significant level of enzyme activity, which is different from the enzyme of the parental cells by several criteria. The variant sublines retained the Qbanded parental karyotype in all their cells. The different characteristics of these variants suggest that indeed they result from independent events. Such variants should prove valuable for studies on the molecular genetics of HGPRT, and also for studies on the regulation of expression of the HGPRT gene (26), the role of HGPRT in the transport of purine bases (23), and the regulation of purine biosynthesis in general $(8,27)$.

\section{ACKNOWLEDGMENTS}

The skillful assistance of Ms. R. Nisani is gratefully acknowledged. During this work J. Epstein was supported by USPHS Postdoctoral, 
Fellowship No. SF22 Ag0503602. This research was supported by USPHS grant No. 5 R01 CA16754-03.

\section{LITERATURE CITED}

1. Szybalski, W. (1964). Cold Spring Harbor Symp. Quant. Biol. 29:151-159.

2. Littlefield, J.W. (1964). Nature 203:1142-1144.

3. Sharp, J.D., Capecchi, N.E., and Capecchi, M.R. (1973). Proc. Natl. Acad. Sci. USA 70:3145-3149.

4. DeMars, R. (1974). Mutation Res. 24:335-364.

5. Siminovitch, L. (1976). Cell 7:1-11.

6. Moore, G.E., and McLimans, W.F. (1968). J. Theor. Biol. 20:217-226.

7. Sato, K., Slesinski, R.S., and Littlefield, J.W. (1972). Proc. Natl. Acad. Sci. USA 69: $1244-1248$.

8. Lever, J.E., Nuki, G., and Seegmiller, J.E. (1974). Proc. Natl. Acad. Sci. USA 71:2679-2683.

9. Nyoromi, O., Sinclair, J.H., and Klein, G. (1972). Exp. Cell Res. 82:241-251.

10. Beratis, N.G., and Hirschhorn, K. (1973). Mamm. Chromosome Newsl. 14:114-116.

11. Hayflick, L. (1965). Tex. Rep. Biol. Med. 23:Supp. 1, 285-303.

12. Schneider, E.L., Stanbridge, E.J., and Epstein, C.J. (1974). Exp. Cell Res. 84:311318.

13. Lowry, O.H., Rosenbrough, N.J., Farr, A.L., and Randall, R.J. (1951). J. Biol. Chem. 193:265-275.

14. Kelley, W.N., and Mead, J.C. (1971). J. Biol. Chem. 246:2953-2958.

15. Arnold, W.J., Mead, J.C., and Kelley, W.N. (1972). J. Clin. Invest. 51:1805-1812.

16. Szybalski, W., Szybalska, E.H., and Ragni, G. (1962). Natl. Cancer Inst. Monagr. 7:75-89.

17. Littlefield, J.W. (1966). Exp. Cell Res. 41:190-196.

18. Albertini, R., and DeMars, R. (1970). Science 169:482-485.

19. Orkin, S.H., and Littlefield, J.W. (1971). Exp. Cell Res. 66:69-74.

20. DeMars, R., and Held, K.R. (1972). Humangenetik 16:87-110.

21. Albertini, R., and DeMars, R. (1973). Mutation Res. 18:199-224.

22. Shapiro, N.D., Khalizev, A.E., Luss, E.V., Marshak, M.I., Petrova, O.N., and Varshaver, N.B. (1972). Mutation Res. 15:203-214.

23. Epstein, J., and Littlefield, J.W. (1977). Exp. Cell Res. in press.

24. Zylka, J.M., and Plagemann, P.G.W. (1975). J. Biol. Chem. 250:5756-5767.

25. Capecchi, M.R., Capecchi, N.E., Hughes, S.H., and Wahl, G.M. (1974). Proc. Natl. Acad. Sci. USA 71:4732-4736.

26. Zielke, H.R., Hong, S., and Littlefield, J.W. (1976). Exp. Cell Res. 97:426-429.

27. Reem, G.H. (1975). Science 190:1098-1099. 